\title{
Genotoxic properties of XLR-11, a widely consumed synthetic cannabinoid, and of the benzoyl indole RCS-4
}

\author{
Franziska Ferk ${ }^{1} \cdot$ Richard Gminski $^{2} \cdot$ Halh Al-Serori ${ }^{1} \cdot$ Miroslav Mišík $^{1} \cdot$ \\ Armen Nersesyan $^{1}$ - Verena J. Koller ${ }^{1}$ - Verena Angerer ${ }^{3}$ - Volker Auwärter ${ }^{3}$. \\ Tao Tang ${ }^{2} \cdot$ Ali Talib Arif ${ }^{2,4} \cdot$ Siegfried Knasmüller ${ }^{1}$
}

Received: 16 October 2015 / Accepted: 4 January 2016 / Published online: 8 February 2016

(c) The Author(s) 2016. This article is published with open access at Springerlink.com

\begin{abstract}
Aim of this study was the investigation of the genotoxic properties of XLR-11 [1-(5-fluoropentyl)- $1 H$-indol-3-yl](2,2,3,3-tetramethylcyclopropyl)methanone, a widely consumed synthetic cannabinoid (SC), and of the benzoyl indole RCS-4 (4-methoxyphenyl)(1-pentyl-1H-indol-3-yl)methanone). We characterized the DNA-damaging properties of these drugs in different experimental systems. No evidence for induction of gene mutations was detected in bacterial (Salmonella/microsome) tests, but clear dosedependent effects were found in in vitro single cell gel electrophoresis (SCGE) assays with human lymphocytes and with buccal- and lung-derived human cell lines (TR146 and A-549). These experiments are based on the determination of DNA migration in an electric field and enable the detection of single- and double-strand breaks and apurinic sites. Furthermore, we found that both drugs induce micronuclei which are formed as a consequence of chromosomal aberrations. The lack of effects in SCGE experiments with lesion-specific enzymes (FPG, Endo III) shows that the DNA damage is not caused by formation of oxidatively damaged bases; experiments with liver enzyme
\end{abstract}

Siegfried Knasmüller

siegfried.knasmueller@meduniwien.ac.at

1 Department of Internal Medicine 1, Institute of Cancer Research, Medical University of Vienna, Borschkegasse 8A, 1090 Vienna, Austria

2 Environmental Health Sciences and Hospital Infection Control, Medical Center, University of Freiburg, 79106 Freiburg, Germany

3 Institute of Forensic Medicine, Medical Center, University of Freiburg, 79104 Freiburg, Germany

4 Institute of Earth and Environmental Science Geochemistry, University of Freiburg, 79104 Freiburg, Germany homogenates and bovine serum albumin indicate that the drugs are not converted enzymatically to DNA-reactive intermediates. Furthermore, results with buccal- and lungderived human cells show that gaseous treatment of the cells under conditions which reflect the exposure situation in drug users may cause damage of the genetic material in epithelia of the respiratory tract. Since DNA instability is involved in the etiology of cancer, these findings can be taken as an indication that consumption of the SCs may cause tumors in the respiratory tract of consumers.

Keywords Synthetic cannabinoids - Genotoxicity · SCGE assay · Micronucleus assay

$\begin{array}{ll}\text { Abbreviations } & \\ \text { 2-AA } & \text { 2-Aminoanthracene } \\ \text { BN-MN } & \text { Binucleated cells with micronucleus } \\ \text { CBMN assay } & \text { Cytokinesis-block micronucleus assay } \\ \text { CBPI } & \text { Cytokinesis-block proliferation index } \\ \text { CT } & \text { Cytostasis } \\ \text { 2-NF } & \text { 2-Nitrofluorene } \\ \text { MN } & \text { Micronucleus } \\ \text { MNi } & \text { Micronuclei } \\ \text { Nbuds } & \text { Nuclear buds } \\ \text { 4-NQO } & \text { 4-Nitroquinoline- } N \text {-oxide } \\ \text { NPBs } & \text { Nucleoplasmic bridges } \\ \text { PHA } & \text { Phytohemagglutinin } \\ \text { RCS-4 } & \text { (4-Methoxyphenyl)(1-pentyl-1 } H \text {-indol- } \\ & \text { 3-yl)methanone } \\ \text { SCGE } & \text { Single cell gel electrophoresis } \\ \text { SCs } & \text { Synthetic cannabinoids } \\ \text { THC } & \text { Tetrahydrocannabinol } \\ \text { XLR-11 } & \text { [1-(5-Fluoropentyl)-1H-indol-3-yl] } \\ & \text { (2,2,3,3-tetramethylcyclo-propyl) } \\ & \text { methanone }\end{array}$




\section{Introduction}

Synthetic cannabinoids ( $\mathrm{SCs}$ ) are drugs which bind to the cannabinoid receptors $\mathrm{CB}_{1}$ and $\mathrm{CB}_{2}$. They cause similar psychotropic effects as $\Delta^{9}$-tetrahydrocannabinol $\left(\Delta^{9}\right.$ THC). These compounds are marketed worldwide in form of herbal mixtures ("legal highs") as a surrogate for marijuana (Spaderna et al. 2013).

The toxic properties of these drugs are in general only poorly investigated. We found in a recent investigation with human-derived cells that some of them cause damage of the genetic material, while other toxic effects (acute cytotoxicity, immunological effects and estrogenic properties) were only moderate or lacking (Koller et al. 2013, 2014). Genetic damage is involved in etiology of various diseases, i.e., it plays a key role in the induction of cancer and is also involved in neurodegenerative disorders, atherosclerosis, infertility and aging (Ames and Gold 1997; Ames et al. 1993). Therefore, our previous findings indicate that adverse effects, which are related to DNA damage, may be induced in users of these drugs.

Aim of the present study was the characterization of the genotoxic properties of XLR-11, a tetramethylcyclopropyl indole drug. This compound was one of the most widely used SCs in the USA and in the Europe and replaced several other drugs such as JWH-018 and AM-2201 (Uchiyama et al. 2013). It was named after the first fuel rocket developed in the USA and binds to both cannabinoid receptors (Wiley et al. 2013). Furthermore, we included in the present investigation also experiments with RCS-4, an indole-based SC which contains a benzoyl ring. It is structurally related to other drugs such as AM-694 and RCS-8 (Logan et al. 2012) and less frequently consumed than XLR-11 (Seely et al. 2013). Figure 1a, b depicts the chemical structures of the two compounds.
We used different experimental models to characterize the genotoxic properties of these drugs including bacterial mutagenicity tests with Salmonella typhimurium strains which detect gene mutations (Maron and Ames 1983) and single cell gel electrophoresis (SCGE or "comet") assays which are based on the measurement of migration of DNA in an electric field and detect single- and doublestrand DNA breaks and apurinic sites (Tice et al. 2000). These experiments were conducted with the buccal-derived human cell line TR146 (Rupniak et al. 1985) and additionally with peripheral human lymphocytes. To determine whether the drugs are converted by phase I enzymes to DNA-reactive intermediates, further SCGE experiments were conducted with liver enzyme homogenate and bovine serum albumin. The formation of oxidatively damaged DNA was assessed in comet experiments by use of lesionspecific enzymes (formamidopyrimidine DNA glycosylase and endonuclease III).

Since "comets" disappear as a consequence of repair processes, it is not clear whether they cause persisting alterations of the genetic material. To clarify this question, we studied in subsequent experiments the induction of micronuclei (MNi) which are formed as a consequence of structural and numerical chromosomal aberrations and of other nuclear anomalies in cytome assays (Fenech 2007).

Finally, experiments were conducted with an Air-liquid interface exposure system which allows investigation of the genotoxic and acute toxic effects of the drugs under realistic exposure conditions. It mimics the physiological conditions in the respiratory tract and eliminates the interactions of potential constituents with culture media (Thorne and Adamson 2013). These experiments were conducted with the buccal cells (TR-146) and with the human cell line A-459 which is derived from lung fibroblasts (Lieber et al. 1976) and was used in earlier gaseous exposure experiments (Majeed et al. 2014; Tang et al. 2012).
Fig. 1 Chemical structures of the test compounds. a RCS-4 (4-methoxyphenyl)(1-pentyl$1 H$-indol-3-yl)methanone, CAS 1345966-78-0), b XLR-11 ([1-(5-fluoropentyl)- $1 H$-indol3-yl](2,2,3,3-tetramethylcyclopropyl)methanone, CAS 1364933-54-9)

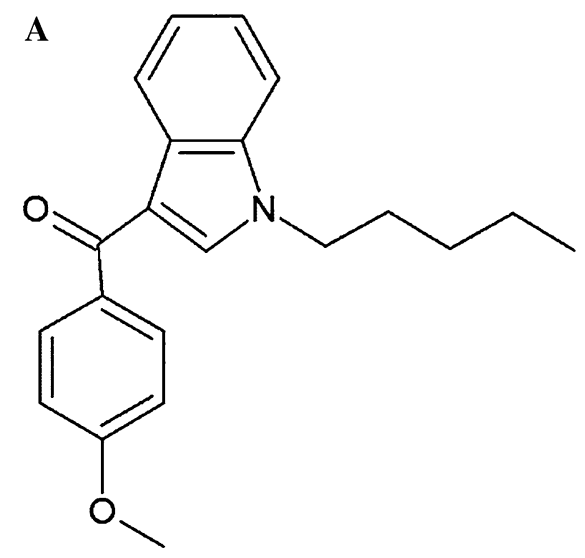




\section{Materials and methods}

\section{Chemicals}

Low-melting-point agarose (LMPA) and normal-meltingpoint agarose (NMPA) were obtained from Gibco (Paisley, UK). Inorganic salts, 2-aminoanthracene (2-AA), dimethyl sulfoxide (DMSO), propidium iodide, hydrogen peroxide, RPMI 1640, Triton X-100, Trizma base, trypan blue, Histopaque 1077, fetal calf serum (FCS), bovine serum albumin (BSA), 2-nitrofluorene (2-NF), 4-nitroquinoline- $N$-oxide (4-NQO), mitomycin C, cytochalasin-B, Dulbecco's phosphate-buffered saline (DPBS), Dulbecco's modified Eagle's medium (DMEM), L-glutamine and sodium pyruvate were purchased from Sigma-Aldrich (Steinheim, Germany). Phytohemagglutinin (PHA) was ordered from Remel Inc., (Lenexa, USA). Aroclor ${ }^{\mathrm{TM}}$ 1254-induced rat liver S9 was purchased from Trinova Biochem GmbH (Giessen, Germany). Trypsin-EDTA was obtained from Life Technologies (Karlsruhe, Germany).

\section{Test compounds}

The synthetic cannabinoids (4-methoxyphenyl)(1-pentyl$1 H$-indol-3-yl)methanone, (RCS-4, CAS 1345966-78$0 ; \quad \mathrm{C}_{21} \mathrm{H}_{23} \mathrm{NO}_{2}$ ) and [1-(5-fluoropentyl)-1 $H$-indol-3-yl] (2,2,3,3-tetramethyl-cyclopropyl)methanone (XLR-11, CAS 1364933-54-9; $\mathrm{C}_{21} \mathrm{H}_{28} \mathrm{FNO}$ ) were provided as crystalline solids (purity $\geq 98 \%$ ) by the State Bureau of Criminal investigation Baden-Württemberg and the Finnish customs, respectively. Stock solutions were prepared in DMSO and stored at $-20{ }^{\circ} \mathrm{C}$.

\section{Salmonella/microsome assays}

The compounds were tested in Ames microplate format (MPF) assays according to the instructions of the manufacturer [Ames MPFTM, Xenometrix AG, Allschwil, Switzerland; see also Fluckiger-Isler and Kamber (2012)]. This procedure differs from the plate incorporation protocol as it is performed in liquid medium with 384 -well microplates and it was used as lower amounts of the test compounds that are required than in plate incorporation experiments. The experiments were conducted with the $S$. typhimurium strains TA98 (hisD3052, rfa, $\Delta$ bio, uvrB, pKM101) and TA100 (hisG46, rfa, $\Delta$ bio, uvrB, pKM101). TA100 detects base pair substitutions while TA98 is sensitive towards mutagens which cause frameshifts (Maron and Ames 1983).

Different concentrations of the drugs $(0.01,0.1$ and $1.0 \mathrm{mM}$ ) were tested in the presence and absence of metabolic activation mix (S9). 4-Nitroquinoline- $N$-oxide (4-NQO, $0.1 \mu \mathrm{g} / \mathrm{mL}$ ) and 2-nitrofluorene (2-NF, $0.4 \mu \mathrm{g} /$
$\mathrm{mL}$ ) were used as positive controls in assays without metabolic activation. 2-Aminoanthracene (2-AA, $5.0 \mu \mathrm{g} /$ $\mathrm{mL}$ ) was used as positive control in all experiments with S-9 mix. Stock solutions of the test compounds were prepared with DMSO which was also added to control cultures according to the instructions of the manufacturer (Ames MPFTM, Xenometrix AG, Allschwil, Switzerland).

Mutagenic effects were determined by measuring changes of the color of the wells from purple to yellow. The number of wells which contained his ${ }^{+}$revertants was counted and compared with the solvent control. Each dose was tested in triplicate.

\section{Collection of lymphocytes}

Peripheral blood samples were collected from three healthy, non-smoking male volunteers without any history of recent disease or exposure to toxic chemical agents. The samples were collected by venipuncture in heparinized tubes (BD, Heidelberg, Germany). Blood samples were collected for comet and MN assays on separate days from the same individuals.

For comet assays, blood samples from three donors were centrifuged $\left(650 \mathrm{~g}, 10 \mathrm{~min}, 4{ }^{\circ} \mathrm{C}\right)$ immediately after collection. Subsequently, the plasma was removed, the cell suspensions were diluted with RPMI 1640, and the lymphocytes were isolated by gradient centrifugation $\left(800 g, 16{ }^{\circ} \mathrm{C}\right.$ min, $\left.16{ }^{\circ} \mathrm{C}\right)$ with Histopaque 1077 in Accuspin tubes (Sigma-Aldrich, Steinheim, Germany). The cells were collected and washed twice in RPMI 1640 (332g, 10 min $16{ }^{\circ} \mathrm{C}$ ), suspended in freezing medium (Biofreeze, Biochrom AG, Berlin, Germany) and stored at $-80{ }^{\circ} \mathrm{C}$.

Blood samples for cytokinesis-block micronucleus (CBMN) assays were collected from the same volunteers. The isolation of lymphocytes was performed as described by Fenech (2007). The cells were cultivated under standard conditions $\left(37{ }^{\circ} \mathrm{C}\right.$, humidified atmosphere, $\left.5 \% \mathrm{CO}_{2}\right)$ in RPMI 1640 medium supplemented with $10 \%$ FCS.

\section{Cultivation of human cell lines (TR-146 and A-549)}

The human cell line TR-146 is derived from buccal epithelial tissue (Rupniak et al. 1985). The cells were obtained from J.G. Rheinwald (Dermatology Institute of Boston, MA USA). They were cultured under standard conditions $\left(37^{\circ} \mathrm{C}\right.$, humidified atmosphere, $5 \% \mathrm{CO}_{2}$ ) in DMEM which was supplemented with $10 \%$ FCS. The cell line was stored in liquid nitrogen and was used for the experiments after recultivation at the fourth to the sixth passage from the stock cultures. The media were changed every 2-3 days; when the cultures had reached confluence, the cells were washed with Dulbecco's phosphate-buffered saline (DPBS, 
Sigma-Aldrich, Steinheim, Germany), detached with Trypsin/EDTA, centrifuged and sub-cultured.

The human lung fibroblast line A-549 was obtained from the American Type Culture Collection (ATCC, Manassas, USA). The cells were used as an in vitro model for type II pulmonary epithelial cells and cultivated in RPMI 1640 medium (low glucose, with L-glutamine), supplemented with $10 \% \mathrm{FCS}$ and $\mathrm{U} / \mathrm{mL}$ penicillin/streptomycin (Invitrogen, Darmstadt, Germany) under humidified conditions $\left(5 \% \mathrm{CO}_{2}\right.$; humidified atmosphere, $\left.37{ }^{\circ} \mathrm{C}\right)$. Frozen human lung fibroblast cells were thawed and used for the experiments after the fourth to the sixth passage. Every 2-3 days, the medium was changed. At 85-90\% confluence, the cells were washed with Dulbecco's PBS ( $\mathrm{Ca}-\mathrm{Mg}$-free), then harvested using $0.25 \%$ trypsin-EDTA and sub-cultured in $\mathrm{T}-25 \mathrm{~cm}^{2}$ flasks (Greiner Bio-One, Austria) or seeded on inserts.

\section{Single cell gel electrophoresis (SCGE) assays under standard conditions}

SCGE assays were conducted under standard alkaline conditions (Tice et al. 2000). Frozen lymphocytes were thawed in a water bath $\left(37^{\circ} \mathrm{C}\right)$ and centrifuged $(200 \mathrm{~g}, 5 \mathrm{~min}$ at $\left.16{ }^{\circ} \mathrm{C}\right)$. Subsequently, the pellets were dissolved in RPMI 1640 and washed twice.

Aliquots of lymphocyte suspensions or of TR-146 cells $\left(1 \times 10^{5}\right.$ cells) were treated (lymphocytes for $3 \mathrm{~h}$, TR-146 for $24 \mathrm{~h}$ ) with different concentrations $(50-150 \mu \mathrm{M})$ of the synthetic cannabinoids. $\mathrm{H}_{2} \mathrm{O}_{2}(50 \mu \mathrm{M})$ was used as a positive control. Solutions of the drugs were prepared from deep-frozen stocks before each experiment and further dissolved in serum-free medium. After incubation in the dark $\left(37{ }^{\circ} \mathrm{C}\right)$, shaking $(250 \mathrm{rpm})$, the cells were washed twice with RPMI 1640 (containing $10 \%$ FCS) and centrifuged $\left(200 \mathrm{~g}, 8 \mathrm{~min}, 16{ }^{\circ} \mathrm{C}\right)$. After centrifugation, the cytotoxic activities of the drugs were determined with the trypan blue exclusion test (Lindl and Bauer 1994); then the pellets were re-suspended in low-melting-point agarose (0.5\% LMPA). Subsequently, the cells were spread on pre-coated agarose slides (1.5\% NMPA) and lysed in the dark at $4{ }^{\circ} \mathrm{C}$ for at least $60 \mathrm{~min}$. After $30 \mathrm{~min}$ unwinding under alkaline conditions ( $\mathrm{pH}>13$ ), electrophoresis was carried out for $30 \mathrm{~min}$ $\left(300 \mathrm{~mA}, 1.0 \mathrm{~V} / \mathrm{cm}\right.$, at $\left.4{ }^{\circ} \mathrm{C}\right)$ and neutralization was performed twice for $8 \mathrm{~min}$. Air-dried slides were stained with propidium iodide $(10 \mu \mathrm{g} / \mathrm{mL})$; subsequently the percentage of DNA in the tails was measured by use of a computeraided image analysis system (Comet IV, Perceptive Instruments Ltd., Burry St. Edmunds', UK). For each experimental point, three slides were prepared from each donor and 50 nuclei were evaluated randomly from each slide.

In addition to the dose-response experiments, assays were performed in which we investigated the impact of rat liver enzyme homogenate (S9) and bovine serum albumin (BSA) on comet formation. The incubation mixtures contained the indicator cells $\left(1 \times 10^{5}\right.$ cells $)$, solutions of the two drugs (final concentration $150 \mu \mathrm{M}$ ) and either PBS or fresh S-9 mix (final protein concentration $30 \mathrm{mg} / \mathrm{mL}$ ) which was prepared according to the standard recipe of Maron and Ames (1983) or BSA solution (30 mg protein/ $\mathrm{mL})$. The mixtures were incubated for $3 \mathrm{~h}\left(37^{\circ} \mathrm{C}\right.$; shaking $250 \mathrm{rpm}$ ); subsequently the cells were washed and processed as described above.

\section{Single cell gel electrophoresis (SCGE) assays with lesion-specific enzymes}

To assess the impact of the drugs on formation of oxidatively damaged purines and pyrimidines, additional experiments with lesion-specific enzymes (formamidopyrimidine DNA glycosylase, FPG and endonuclease III, Endo III) were conducted according to the protocol of Collins and Dušinská (2002). The cells (TR-146) were exposed to the test compounds as described above. To establish the optimal amounts of the enzymes, calibration experiments were carried out according to the protocol of Collins et al. (1997) before the main experiments (results not shown).

After lysis, the slides were washed twice with enzyme reaction buffer $(\mathrm{pH} 8.0)$ for $8 \mathrm{~min}$. Subsequently, the nuclei were treated either with $50 \mu \mathrm{L}$ of the enzyme solutions or with the enzyme buffers. The incubation time for FPG was $30 \mathrm{~min}$ and for Endo III $45 \mathrm{~min}$ at $37^{\circ} \mathrm{C}$, respectively. After the treatment, electrophoresis was carried out under standard conditions $(30 \mathrm{~min}, 300 \mathrm{~mA}, 1.0 \mathrm{~V} / \mathrm{cm}$, at $\left.4{ }^{\circ} \mathrm{C}, \mathrm{pH}>13\right)$. After lysis and electrophoresis, the slides were processed and evaluated as described above. For each experimental point, two cultures were made. From each culture, two slides were prepared and 50 cells were evaluated from each slide. The values which were obtained with the enzyme buffers were subtracted from the results which were obtained with the enzyme solutions.

\section{Cytokinesis-block micronucleus (CBMN) assays with human lymphocytes and TR-146 cells}

Lymphocyte cultures were set up according to the recommendations of Fenech (2007) in agreement with the OECD guideline 487 (OECD 2010). Since human lymphocytes are more sensitive toward genotoxins during S, G2 and $M$ phase than freshly collected cells which are in the G0 phase, mitogenic stimulation was performed with PHA before treatment of the cells with the test compounds.

Briefly, $1 \times 10^{6}$ lymphocytes were added to $750 \mu \mathrm{L}$ culture medium (RPMI 1640 containing $10 \%$ FCS, 2.0 mM L-glutamine and $1.0 \mathrm{mM}$ sodium pyruvate) and $10 \mu \mathrm{L}$ of a PHA solution $(30 \mu \mathrm{g} / \mathrm{mL})$ to stimulate cell division. For each 
experimental point, two cultures were made; they were incubated at $37{ }^{\circ} \mathrm{C}$ in humidified atmosphere with $5 \% \mathrm{CO}_{2}$ with PHA for $44 \mathrm{~h}$. Subsequently, the medium was replaced by fresh medium without FCS which contained different concentrations of the drugs $(25.0,50.0,75.0,100.0$ and $150.0 \mu \mathrm{M})$. Treatment was performed for $3 \mathrm{~h}\left(37^{\circ} \mathrm{C}\right.$, shaking $250 \mathrm{rpm}$ in the dark). Cytochalasin-B was added to the cultures at a final concentration of $4.5 \mu \mathrm{g} / \mathrm{mL}$ to block cytokinesis after treatment with the drugs. Mitomycin $\mathrm{C}(1.0 \mu \mathrm{g} / \mathrm{mL})$ was used as a positive control; serum-free medium with DMSO (1.0\%) was added to untreated cultures as a solvent control. After the treatment, the cells were washed twice with RPMI 1640 $\left(332 g, 10 \mathrm{~min} ., 16^{\circ} \mathrm{C}\right)$ and the pellets re-suspended in culture medium. The cells were harvested after $72 \mathrm{~h}$. Slides were made with the cyto-centrifugation method (Fenech 2007); after drying, they were fixed and stained with Diff Quick (Dade Behring, Deerfield, IL, USA).

The protocol for experiments with TR-146 is described in detail in the paper of Koller et al. (2014). Briefly, the cells were seeded in 6-well plates and allowed to attach overnight. Subsequently, the medium was removed, and the cells were washed with DPBS; then they were treated with different concentrations of the test compounds in serumfree medium for $24 \mathrm{~h}$. Mitomycin C $(1.0 \mu \mathrm{g} / \mathrm{mL})$ was used as a positive control; medium with DMSO (1\%) was used in the control cultures. After exposure of the cells to the drugs and washing with PBS, they were incubated with cytochalasin-B $(3.0 \mu \mathrm{g} / \mathrm{mL})$ and DMEM (with $10 \%$ FCS) for another $24 \mathrm{~h}$. Subsequently, the cells were washed, trypsinized and processed as described above.

From each culture, 2000 cells were evaluated. Different endpoints were scored, namely mono-nucleated, binucleated (BN) and multi-nucleated cells as well as the rates of binucleated cells with $\mathrm{MN}(\mathrm{BN}-\mathrm{MN})$, the total number $\mathrm{MN}$ in binucleated cells (MNi), nuclear buds (Nbuds) and nucleoplasmatic bridges (NPBs). The cytokinesis-block proliferation indices (CBPI) were calculated with 500 cells according to the formula $\mathrm{CBPI}=[\mathrm{M} 1+2 \mathrm{M} 2+3(\mathrm{M} 3+\mathrm{M} 4)] / \mathrm{N}(\mathrm{N}$ is the total number of scored cells, M1 - M4 refers to the number of cells with one to four nuclei). The toxicity of the compounds was indirectly assessed by the assumption that a CBPI of 1.0 corresponds to $100 \%$ cytotoxicity. Five concentrations of each drug were used to determine the CBPI values. In agreement with OECD guideline 487 (OECD 2010), only doses were analyzed in regard to formation of $\mathrm{MN}$ and other nuclear anomalies which caused less than $60 \%$ cytotoxicity.

\section{Determination of acute toxic and genotoxic properties of the drugs by use of air-liquid interface exposure system}

The experiments were conducted with the VITROCELL ${ }^{\circledR}$ cultivation and exposure system (12 HT/HT CF modules
Waldkirch, Germany) with 6 cell culture inserts which is based on the cultivation of cells on porous membrane (Majeed et al. 2014). The system has separate exposure modules, each positioning three inserts which were used for parallel exposures to controls and test compounds. The aerosol is humidified up to $80 \%$ under controlled temperature. The cells are nourished with serum-free medium from the basal surface, while being exposed to the aerosolized test compound in airliquid interface (ALI) from the top that was flowing perpendicular onto the surface with constant air flow $(5 \mathrm{~mL} / \mathrm{min})$.

The experiments were performed as described in an article of Weber et al. (2013) with slight modifications. The indicator cells (TR-146 and A-549, $1 \times 10^{5}$ cells per insert) were transferred and grown in special Transwell ${ }^{\circledR}$ inserts (ThinCerts ${ }^{\mathrm{TM}}$ Cell Culture Inserts, Greiner Bio-One, Frickenhausen, Germany) for $24 \mathrm{~h}$ before each experiment. Before the exposure, the media were removed from the apical surface of the cultures and transferred in sterile environment into the VITROCELL ${ }^{\circledR}$ exposure system.

The cannabinoids (5 and $20 \mathrm{mg}$ of each drug) were vaporized by a commercial vaporizer (Vaporizer-BLKTitan, Near Dark GmbH, Hennef, Germany). Briefly, the drugs were placed inside the heating chamber of the apparatus and the temperature set on $220{ }^{\circ} \mathrm{C}$ to vaporize the chemicals. The cells were exposed to the vaporized drugs for $10 \mathrm{~min}$ (flow rate $5 \mathrm{~mL} / \mathrm{min} /$ well) on the air-liquid interfaces via trumpets raised $0.5 \mathrm{~cm}$ above the cell layers. Flow and vacuum rates within the system were set using mass flow meters (Analyt-MTC GmbH, Mülheim, Germany). For each experimental point, two cultures were exposed from each culture and three slides were made. The experiments were conducted in duplicate.

After the treatment, the inserts were removed and transferred back to regular 12-well plates. Complete medium with $10 \%$ FBS was added to both (the apical and the basal) surfaces. Subsequently, the cells were cultivated in an incubator, and then, the cultures were trypsinized and the cells analyzed in SCGE assays as described above. The cytotoxic effects of the drugs were monitored in all experiments with the trypan blue exclusion test (Lindl and Bauer 1994).

\section{Determination of concentrations of SCs in two cell lines}

Quantification of the synthetic cannabinoids in cells was done using a LC/ESI-MS/MS system consisted of a QTrap ${ }^{\circledR}$ 4000 mass spectrometer fitted with a TurbolonSpray interface (AB Sciex, Darmstadt, Germany), and a Shimadzu Prominence HPLC system (Duisburg, Germany) was used. Chromatographic separation was achieved using the conditions of Huppertz et al. (2014) with a Kinetex ${ }^{\circledR} 2.6$ u C18 $100 \AA$ Á, $100 \times 2.1 \mathrm{~mm}$ column (Phenomenex Ltd., Aschaffenburg, Germany) with a matching guard column and gradient elution with a flow rate of $0.5 \mathrm{~mL} / \mathrm{min}$ (Huppertz et al. 2014). 
The scheduled multiple reaction monitoring (SMRM) method contained two transitions for XLR-11, XLR-11 Isomer and RCS-4 and one transition for the ISTD. The MRM transitions were only recorded in a time window of $\pm 50 \mathrm{~s}$ around the expected retention time. For all compounds, the declustering potential (DP), the entrance potential (EP), the collision energy (CE) as well as the cell exit potential (CXP) were optimized. The mass spectrometer was operated in positive ionization mode. The method used was fully validated according to the guidelines of GTFCh; LODs are $0.04 \mathrm{ng} / \mathrm{mL}$ for RCS- 4 and $0.03 \mathrm{ng} / \mathrm{mL}$ for XLR11 and its isomer. Quantification was done using a 5-point calibration in the range of $0.1-1.25 \mathrm{ng} / \mathrm{mL}$. After exposure of the cells $\left(1 \times 10^{5} /\right.$ insert $)$ grown on the inserts, they were sonicated with $1000 \mu \mathrm{L} \mathrm{MeOH}$, and subsequently, concentrations of the drugs were determined.

\section{Statistical analyses}

All results were analyzed with GraphPad Prism 5 software system (LaJolla, CA, US). The data from the bacterial tests, from the SCGE experiments and from the MN assays are presented as mean $\pm \mathrm{SD}$.

The results of CBMN assays were analyzed with the Kruskal-Wallis test followed by Dunn's test. The findings of SCGE assays (under standard conditions and after treatment with lesion-specific enzymes) were analyzed by oneway ANOVA followed by Dunnett's multiple-comparisons test. The Student's $t$ test was used to analyze the data after liquid exposure to the drugs. Differences were considered as significant, when the $p$ values were $\leq 0.05$.

Results from Ames MPF assays were evaluated according to Fluckiger-Isler and Kamber (2012). Briefly, the mean numbers of positive (yellow) wells per dose were calculated from triplicates, and the fold increase above the baseline values was determined for each dose (for further details, see Fluckiger-Isler and Kamber 2012). A $\geq 2$-fold increase compared to the baseline (control) value was considered as a positive result.

\section{Results}

\section{Salmonella/microsome assays}

The results of representative bacterial mutagenicity tests are summarized in Table 1. It can be seen that negative results were obtained with both drugs under all experimental conditions, while clear effects were found with the positive controls.

\section{Single cell gel electrophoresis experiments (standard conditions)}

Figure 2 depicts the results which were obtained with the drugs in the SCGE experiments with lymphocytes (Fig. 2a, b) and with TR-146 cells (Fig. 2c, d). With both SCs, dosedependent induction of DNA migration was found in both cell lines. The doses which were required to cause significant effects were in most experimental series $\geq 100 \mu \mathrm{M}$; with RSC-4, a clear effect was seen in the buccal-derived cells already with $50 \mu \mathrm{M}$. The positive control $\left(\mathrm{H}_{2} \mathrm{O}_{2}\right.$, $50 \mu \mathrm{M}$ ) induced in all experiments significant induction of DNA migration.

The cytotoxic effects of the drugs were monitored with the trypan blue exclusion test (Lindl and Bauer 1994). The ratio of
Table 1 Results of gene mutation assays obtained with the bacterial indicator strain, Salmonella typhimurium TA98 and TA100 in the presence and absence of metabolic activation $\operatorname{mix}$

\begin{tabular}{llcccc}
\hline Compounds & $\begin{array}{l}\text { Concentration } \\
\mathrm{mM}\end{array}$ & $\begin{array}{c}\text { TA98 }-\mathrm{S} 9 \\
\text { Mean } \pm \mathrm{SD}\end{array}$ & $\begin{array}{c}\text { TA98 }+\mathrm{S} 9 \\
\text { Mean } \pm \mathrm{SD}\end{array}$ & $\begin{array}{c}\text { TA100 }-\mathrm{S} 9 \\
\text { Mean } \pm \mathrm{SD}\end{array}$ & $\begin{array}{c}\text { TA100 + S9 } \\
\text { Mean } \pm \text { SD }\end{array}$ \\
\hline Neg. Cont. & 0.00 & $0.7 \pm 0.6$ & $1.3 \pm 1.2$ & $3.7 \pm 0.6$ & $3.7 \pm 1.5$ \\
RCS-4 & 0.01 & $0.3 \pm 0.6$ & $0.7 \pm 1.2$ & $3.7 \pm 1.2$ & $4.0 \pm 3.5$ \\
& 0.10 & $0.3 \pm 0.6$ & $3.0 \pm 1.7$ & $4.7 \pm 0.6$ & $4.0 \pm 2.6$ \\
& 1.00 & $1.0 \pm 1.7$ & $1.7 \pm 0.6$ & $2.7 \pm 0.6$ & $7.6 \pm 1.2$ \\
XLR-11 & 0.01 & $0.3 \pm 0.6$ & $2.3 \pm 1.5$ & $5.3 \pm 2.3$ & $6.3 \pm 2.9$ \\
& 0.10 & $0.3 \pm 0.6$ & $1.7 \pm 1.2$ & $5.0 \pm 2.1$ & $6.7 \pm 1.2$ \\
& 1.00 & $1.0 \pm 1.0$ & $0.7 \pm 1.2$ & $3.3 \pm 1.5$ & $6.0 \pm 2.0$ \\
Pos. Cont. & & $38.3 \pm 1.2 *$ & $48.0 \pm 0.0 *$ & $48.0 \pm 0.0 *$ & $36.0 \pm 1.0 *$ \\
\hline
\end{tabular}

The Salmonella typhimurium strains TA100 and TA98 were exposed to different concentrations of the SCs in the presence and absence of metabolic activation mix (rat liver S9) as described in materials and methods. The results were considered positive when the response was a $\geq 2$-fold increase over that of the baseline. Numbers indicate means \pm SDs of results obtained in three parallel experiments; asterisks indicate values which are significantly different from those found in the respective controls

* Significant differences from the controls cultures $(p<0.05)$

a Positive controls without S9: 4-NQO $(0.1 \mu \mathrm{g} / \mathrm{mL})$ and 2-NF $(0.4 \mu \mathrm{g} / \mathrm{mL})$; with S9: 2-AA $(5.0 \mu \mathrm{g} / \mathrm{mL})$; DMSO was added to the negative controls 


\section{Lymphocytes}
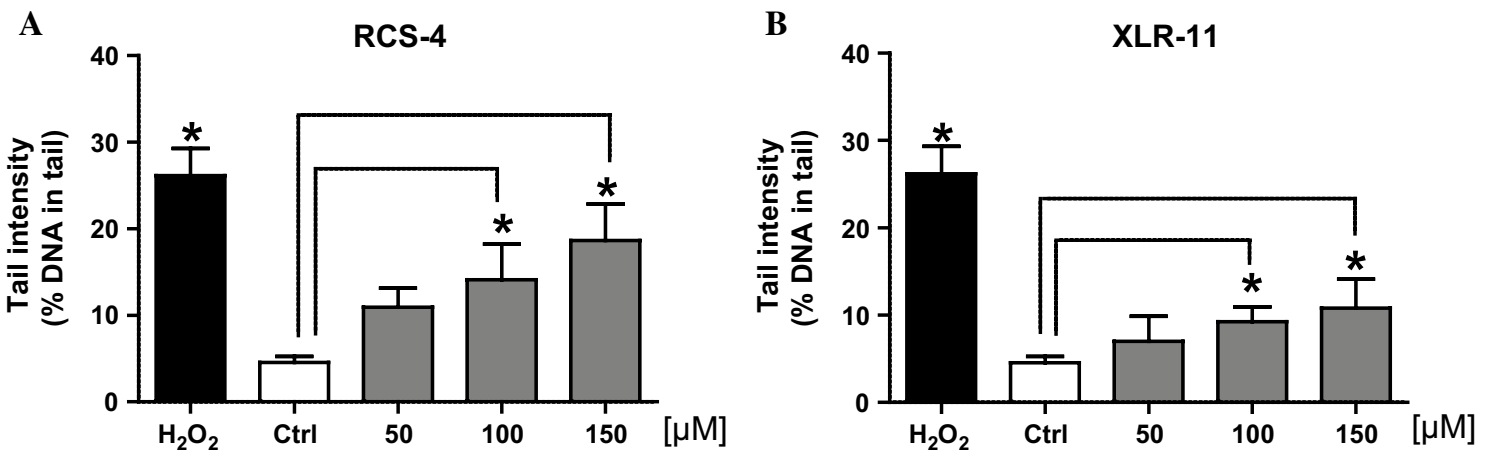

TR-146

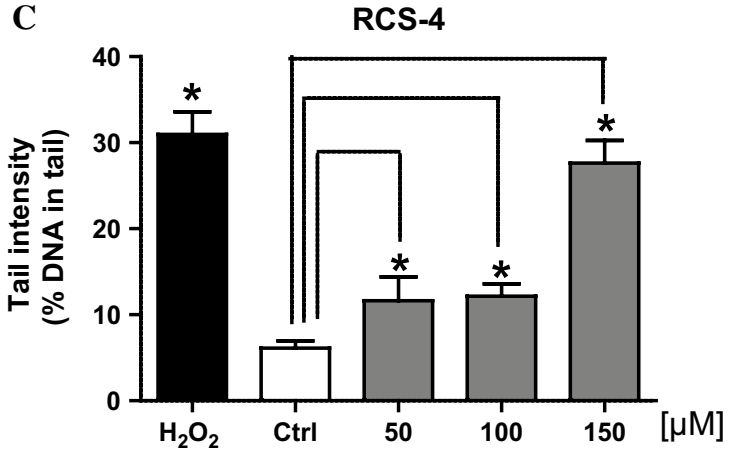

Fig. 2 Impact of treatment of lymphocytes (a, b) and of humanderived buccal cells (TR-146; c, d) with RCS-4 and XLR-11 on comet formation. Lymphocytes were treated for $3 \mathrm{~h}$, TR-146 cells for 24 h. Bars indicate mean \pm SD of results obtained with three par-

"blue" cells (with membrane damage) was in all experiments $<20 \%$; it is known that higher values may cause misleading results in SCGE experiments (Henderson et al. 1998).

\section{SCGE experiments with lesion-specific enzymes}

Several investigations indicate that SCs cause inflammations which may lead to release of reactive oxygen species [for further details, see (Bileck et al. 2015; Jean-Gilles et al. 2015)]. Therefore, we used a modified protocol of the SCGE technique to monitor formation of oxidatively damaged purines and pyrimidines. The results of these experiments are summarized in Fig. 3a-c. It can be seen that no evidence for increased formation of oxidized DNA bases was detected in the present experiments.

\section{SCGE experiments with liver S9 mix and bovine serum albumin}

To find out whether addition of phase I enzymes which are represented in liver-derived homogenate (S9) leads to

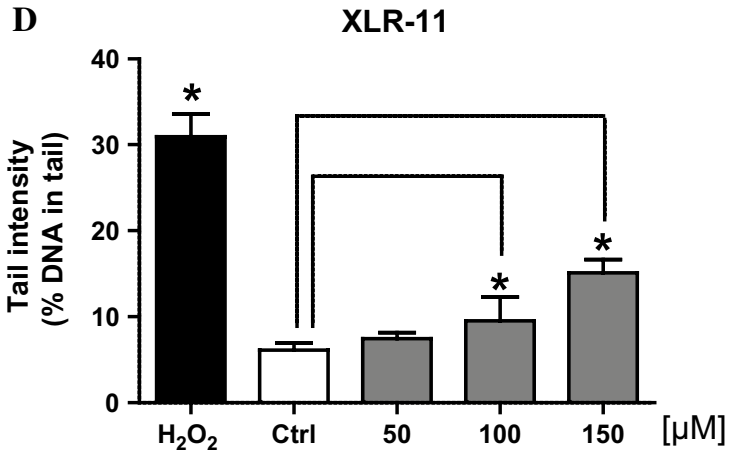

allel cultures per experimental point in a representative experiment (from each culture, 2 slides were made and 50 cells were evaluated per slide). Stars indicate statistical significance ( $p \leq 0.05$, ANOVA)

activation of the drugs, further experiments were carried out. The results are depicted in Fig. $4 \mathrm{a}$, b. It can be seen that the extent of comet formation caused by both drugs was reduced in the presence of the activation mix by 16 and $18 \%$, respectively. A similar effect was seen when the enzyme mix was replaced by BSA solution (which contained an identical amount of protein as the activation mix).

\section{Induction of acute toxic and genotoxic effects after vaporized exposure}

The results of experiments in which the indicator cells were exposed in an air-liquid interface system are summarized in Table 2. Both SCs caused significant induction of DNA migration in the two indicator cell lines. Cytotoxic effects were in all experimental series below $20 \%$ (columns 3 and 4). RCS-4 was in both indicator cell lines a more potent genotoxin, i.e., the extent of comet formation (expressed as $\%$ DNA in the tail) was under identical conditions approximately twofold higher with the benzoyl analog than with XLR-11. 

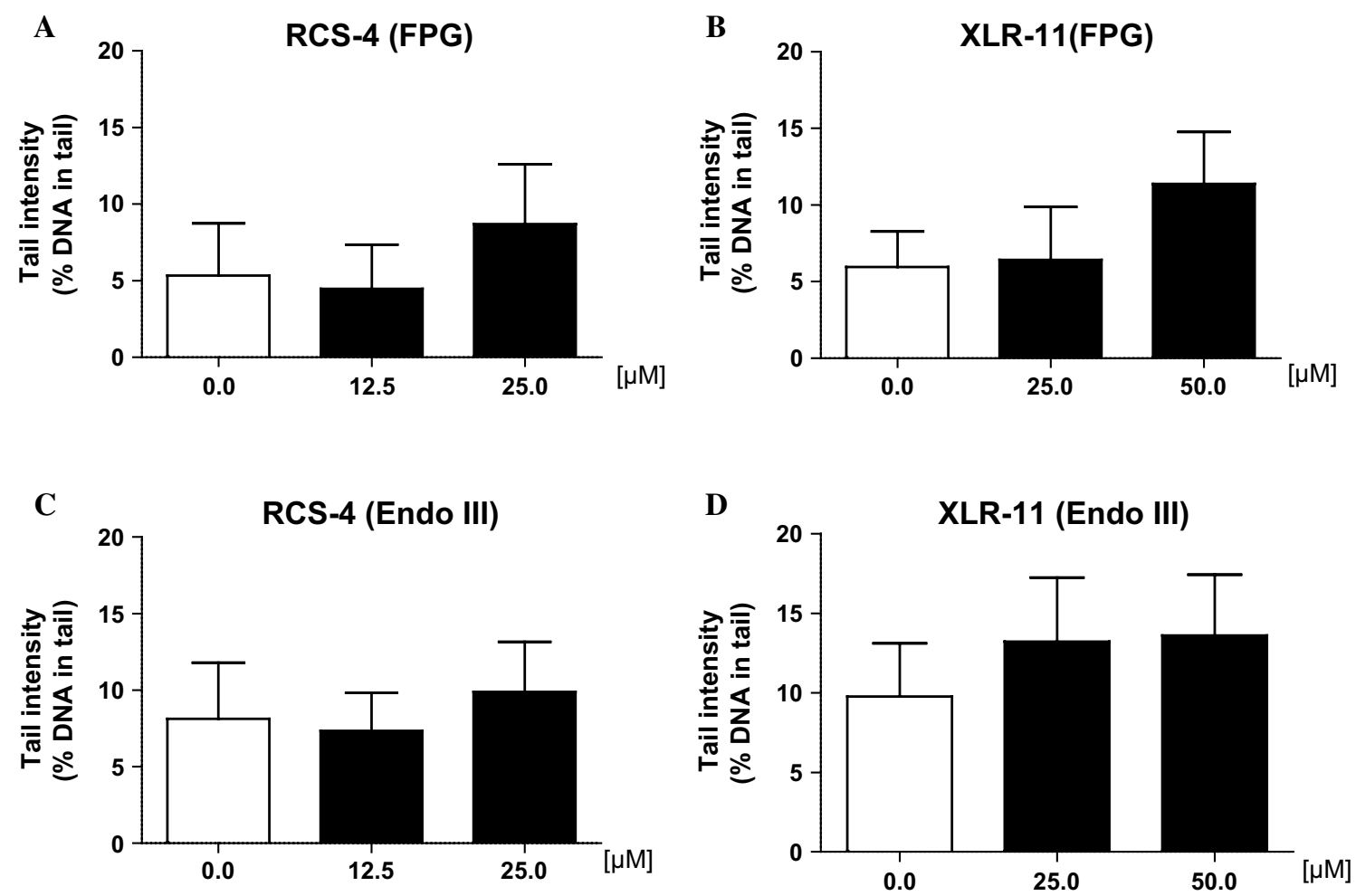

Fig. 3 Impact of treatment of human-derived buccal cells (line TR-146) with synthetic cannabinoids on formation of oxidatively damaged purines (FPG-sensitive sites, a, b) and pyrimidines (Endo III sensitive sites, $\mathbf{c}, \mathbf{d})$. The cells were exposed to the drugs for $24 \mathrm{~h}$. Subsequently, the nuclei were isolated and treated with enzymes or with the buffers only as described in the "Materials and methods"

section. Subsequently, DNA migration was monitored. Bars indicate means \pm SDs of results obtained with two cultures per experimental point in a representative experiment (values which were obtained with the enzyme buffers were subtracted from values which were obtained with the enzymes). From each culture, two slides were made and 50 cells were evaluated per slide

$\mathbf{A}$

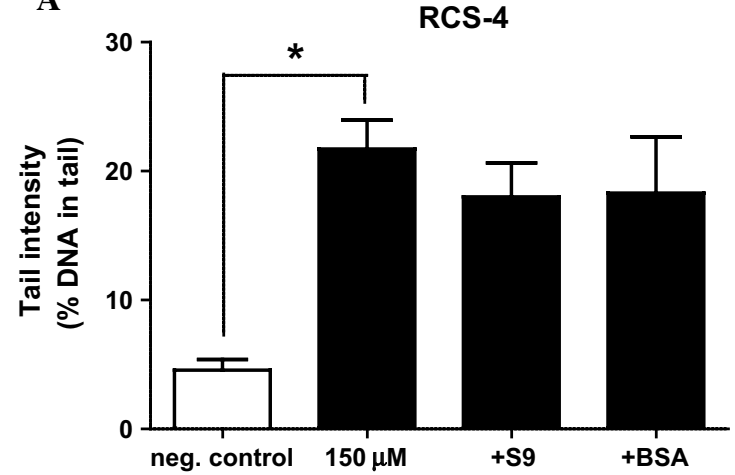

Fig. 4 a, b Impact of rat liver S9 and bovine serum albumin (BSA) on SC-induced DNA migration in human lymphocytes. The cells were treated with solutions of the drugs $(150 \mu \mathrm{M}$ RCS-4 or XLR11) with and without S9 mix or BSA (final protein concentration $0.3 \mathrm{mg} / \mathrm{mL}$ ). After treatment of the cells, DNA migration was deter-
B

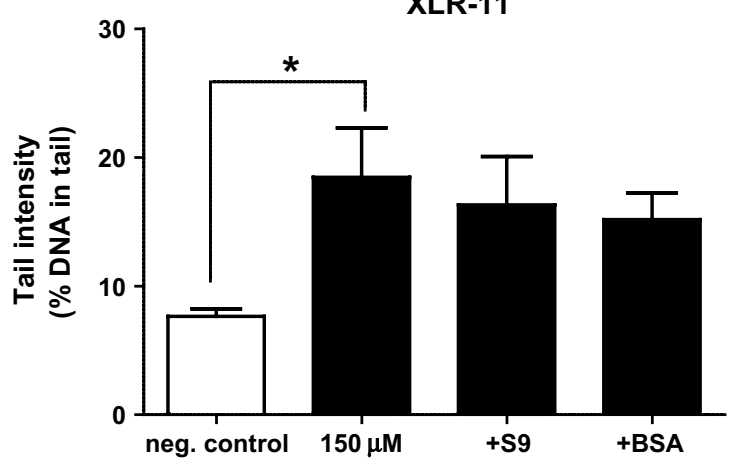

mined in SCGE experiments under standard condition. Bars represent means \pm SDs of results obtained with tree cultures in parallel. From each culture, two slides were made and 50 cells were analyzed for comet formation per slide 
Table 2 Impact of vaporized exposure on the DNA stability in human-derived lung fibroblasts (A-549) and buccal (TR-146) cells

\begin{tabular}{|c|c|c|c|c|c|c|c|}
\hline \multirow[t]{2}{*}{ Compounds } & \multirow[t]{2}{*}{ Dose (mg) } & \multicolumn{2}{|c|}{$\begin{array}{l}\text { HPLC analyses } \\
(\mathrm{ng} / \mathrm{mL})^{\mathrm{a}}\end{array}$} & \multicolumn{2}{|c|}{$\begin{array}{l}\text { Cytotoxic activity } \\
(\% \text { cells of control })^{\mathrm{c}}\end{array}$} & \multicolumn{2}{|c|}{$\begin{array}{l}\text { DNA migration } \\
\text { (\% DNA in tail) }\end{array}$} \\
\hline & & A-549 & TR-146 & A-549 & TR-146 & A-549 & TR-146 \\
\hline \multirow[t]{4}{*}{ RCS-4 } & 0.0 & 0.0 & 0.0 & $96.17 \pm 5.46$ & $97.87 \pm 2.12$ & $2.22 \pm 0.75$ & $2.03 \pm 0.54$ \\
\hline & 5.0 & n.d. ${ }^{b}$ & 1358.0 & $86.33 \pm 3.81$ & $84.93 \pm 2.87$ & $8.10 \pm 2.91 *$ & $6.98 \pm 4.21^{*}$ \\
\hline & 0.0 & 0.0 & 0.0 & $94.67 \pm 4.93$ & $83.33 \pm 1.53$ & $3.72 \pm 0.78$ & $3.55 \pm 1.09$ \\
\hline & 20.0 & n.d. ${ }^{b}$ & 2987.0 & $81.50 \pm 2.27$ & $82.80 \pm 2.52$ & $10.1 \pm 3.20 *$ & $7.04 \pm 1.89 *$ \\
\hline \multirow[t]{4}{*}{ XLR-11 } & 0.0 & 0.0 & 0.0 & $95.50 \pm 3.42$ & $97.87 \pm 2.12$ & $1.76 \pm 0.71$ & $1.63 \pm 0.47$ \\
\hline & 5.0 & 2010.0 & 1847.0 & $89.33 \pm 9.35$ & $87.60 \pm 2.30$ & $3.79 \pm 1.07 *$ & $4.94 \pm 2.03^{*}$ \\
\hline & 0.0 & 0.0 & 0.0 & $95.60 \pm 3.53$ & $91.00 \pm 6.25$ & $2.60 \pm 1.01$ & $2.44 \pm 0.90$ \\
\hline & 20.0 & 3030.0 & 4390.0 & $81.83 \pm 3.54$ & $84.47 \pm 4.15$ & $5.71 \pm 1.42 *$ & $4.68 \pm 1.24 *$ \\
\hline
\end{tabular}

Numbers indicate means \pm SDs of data obtained with three parallel cultures per experimental point in a representative experiment. From each culture, 3 slides were made and 50 cells were evaluated per slide

* Significant differences from the corresponding control (unexposed) cultures (Student's $t$ test, $p \leq 0.05$ ). In each experiment, positive controls were included; i.e., cells were exposed for $5 \mathrm{~min}$ on ice $\mathrm{H}_{2} \mathrm{O}_{2}$ $(50 \mu \mathrm{M})$; in all these experiments, significant induction of DNA migration was observed (data not shown)

${ }^{a}$ Values indicate means of four measurements. $10^{4}$ cells per insert were sonicated with $1000 \mu \mathrm{L} \mathrm{MeOH}$; subsequently, the concentrations of the drug were determined (see "Materials and methods" section)

${ }^{\mathrm{b}}$ n.d. not determined

c Cytotoxicity was evaluated by use of trypan blue exclusion method. Numbers (\%) indicate the ratio of cells with clear cytoplasm (cells without membrane damage) to total number of evaluated cells

\section{Impact of drugs on the induction of micronuclei and other nuclear anomalies}

To find out whether treatment of human cells leads to formation of MN, which reflect structural and numerical chromosomal aberrations, cytome experiments were conducted. The results with lymphocytes and with TR-146 cells are summarized in Table 3.

Both compounds caused in both cell types induction of MNi. A clear effect was found in the lymphocytes with XLR11 with concentrations $\geq 100 \mu \mathrm{M}$, while in buccal-derived cells significant effects were detected already with a lower concentration $(75 \mu \mathrm{M})$. Also RCS-4 caused a positive result in both types of indicator cells. A clear increase in the $\mathrm{MN}$ rates was detected in the lymphocytes with $50 \mu \mathrm{M}$; higher doses could be not evaluated due to inhibition of cell division.

With XLR-11 additionally a significant increase in other nuclear anomalies (Nbuds and NPBs) was observed in the blood cells and also in the buccal cells at high doses (100 and $150 \mu \mathrm{M}$, respectively). The rates of these anomalies were also elevated in both cell types as a consequence of treatment with RCS-4, but these effects were only moderate and did not reach significance.

\section{Discussion}

Three different genotoxicity systems were used in the present study to investigate the genotoxic properties of XLR-11, one of the most widely consumed SCs and, of the benzoyl indole RCS-4. Furthermore, attempts were made to characterize the molecular mechanisms which lead to damage of the genetic material and to find out whether adverse effects can be expected in drug users under realistic exposure conditions.

The negative results which were obtained in the Salmonella/microsome assays indicate that the drugs do not induce gene mutations. These findings were not unexpected; also with other indole SCs including UR-144, which is structurally related to XLR-11 (XLR-11 is the fluorinated form of UR-144) (Mohr et al. 2014), consistently negative results were obtained in earlier bacterial mutagenicity tests (Koller et al. 2015); also the natural cannabinoid $\Delta^{9}$-THC does not cause induction of his ${ }^{+}$ revertants in Salmonella tester strains (NTP 1996). SCs with benzoyl structure like RCS-4 have not been studied before in microbial mutagenicity assays according to our knowledge, and the present findings show that the compound is devoid of activity under all experimental conditions.

On the contrary, clear evidence for induction of DNA damage was found in SCGE experiments which reflect single- and double-strand breaks as well as apurinic sites (Tice et al. 2000) in human lymphocytes and also in the buccal-derived cells (Fig. 2). In this context, it is notable that we observed induction of comet formation by other SCs in earlier experiments; for example, the cyclohexylphenol CP-47,497-C8 caused significant induction of DNA migration in lymphocytes and in TR-146 cells (Bileck et al. 2015; Koller et al. 2014). Also with UR-144 and 
Table 3 Impact of different synthetic cannabinoids on cytokinesis-block proliferation indices and on the rates of various nuclear aberrations in human mitogen-stimulated lymphocytes and in TR-146 cells

\begin{tabular}{|c|c|c|c|c|c|c|c|}
\hline Compounds & $\begin{array}{l}\text { Concentration } \\
\mu \mathrm{M}\end{array}$ & $\begin{array}{l}\text { CBPI } \\
\text { Mean } \pm \text { SD }\end{array}$ & $\begin{array}{l}\mathrm{CT} \\
(\%)\end{array}$ & $\begin{array}{l}\mathrm{BN}-\mathrm{MNi}^{\mathrm{a}} \\
\text { Mean }(\% \circ) \pm \mathrm{SD}\end{array}$ & $\begin{array}{l}\mathrm{MNi}^{\mathrm{b}} \\
\text { Mean }(\% o) \pm \mathrm{SD}\end{array}$ & $\begin{array}{l}\text { Nbuds } \\
\text { Mean }(\% o) \pm \mathrm{SD}\end{array}$ & $\begin{array}{l}\text { NPBs } \\
\text { Mean }(\% o) \pm S D\end{array}$ \\
\hline \multicolumn{8}{|c|}{ Peripheral human lymphocytes } \\
\hline \multirow[t]{6}{*}{ RCS-4 } & 0 & $2.02 \pm 0.14$ & 0.0 & $4.14 \pm 0.52$ & $4.25 \pm 0.49$ & $2.96 \pm 1.55$ & $1.67 \pm 0.75$ \\
\hline & 25 & $1.79 \pm 0.15$ & 22.6 & $6.45 \pm 1.24$ & $6.92 \pm 0.96$ & $3.73 \pm 1.36$ & $2.72 \pm 1.24$ \\
\hline & 50 & $1.52 \pm 0.22 *$ & 49.0 & $8.01 \pm 0.7^{*}$ & $8.46 \pm 1.12 *$ & $3.51 \pm 1.05$ & $2.98 \pm 1.37$ \\
\hline & 75 & $1.25 \pm 0.21^{*}$ & 75.5 & n.e. & n.e & n.e. & n.e. \\
\hline & 100 & $1.19 \pm 0.17 *$ & 81.4 & n.e. & n.e & n.e. & n.e. \\
\hline & 150 & $1.07 \pm 0.11^{*}$ & 80.4 & n.e. & n.e & n.e. & n.e. \\
\hline \multirow[t]{5}{*}{ XLR-11 } & 25 & $1.86 \pm 0.20$ & 16.7 & $7.03 \pm 1.76$ & $7.26 \pm 1.86$ & $4.31 \pm 1.95$ & $1.81 \pm 1.00$ \\
\hline & 50 & $1.69 \pm 0.22 *$ & 32.4 & $6.04 \pm 2.50$ & $6.16 \pm 2.70$ & $3.13 \pm 0.77$ & $2.45 \pm 0.88$ \\
\hline & 75 & $1.59 \pm 0.14^{*}$ & 43.1 & $8.54 \pm 1.02$ & $8.78 \pm 1.02$ & $4.48 \pm 1.02$ & $2.77 \pm 0.66$ \\
\hline & 100 & $1.42 \pm 0.13^{*}$ & 58.8 & $14.51 \pm 4.40^{*}$ & $16.00 \pm 5.71 *$ & $9.08 \pm 3.04^{*}$ & $6.47 \pm 3.02 *$ \\
\hline & 150 & $1.07 \pm 0.05^{*}$ & 93.1 & n.e. & n.e. & n.e. & n.e. \\
\hline Pos. Cont. & $1 \mu \mathrm{g} / \mathrm{mL}$ & $1.73 \pm 0.16$ & & $48.36 \pm 9.37 *$ & $50.62 \pm 10.10^{*}$ & $12.44 \pm 5.91 *$ & $2.68 \pm 1.16$ \\
\hline \multicolumn{8}{|c|}{ Buccal-derived human cells (TR-146) } \\
\hline \multirow[t]{6}{*}{ RCS-4 } & 0 & $2.35 \pm 0.44$ & & $1.39 \pm 0.40$ & $3.44 \pm 0.34$ & $1.34 \pm 0.14$ & $1.32 \pm 0.34$ \\
\hline & 25 & $1.90 \pm 0.75$ & 33.3 & $3.46 \pm 0.91$ & $5.09 \pm 1.09$ & $3.92 \pm 0.89$ & $1.89 \pm 0.97$ \\
\hline & 50 & $1.86 \pm 0.32$ & 36.3 & $4.67 \pm 1.04$ & $6.02 \pm 1.02$ & $3.35 \pm 0.76$ & $1.79 \pm 0.50$ \\
\hline & 75 & $1.80 \pm 0.25$ & 40.7 & $6.89 \pm 1.10^{*}$ & $7.99 \pm 0.90^{*}$ & $3.92 \pm 1.02$ & $1.70 \pm 0.40$ \\
\hline & 100 & $1.35 \pm 0.86^{*}$ & 74.1 & n. e. & n. e & n. e. & n. e \\
\hline & 150 & $1.21 \pm 0.45^{*}$ & 84.4 & n. e. & n. e & n. e. & n. e \\
\hline \multirow[t]{5}{*}{ XLR-11 } & 25 & $1.99 \pm 0.67$ & 26.7 & $3.45 \pm 0.97$ & $5.20 \pm 1.14$ & $2.36 \pm 0.89$ & $1.12 \pm 0.34$ \\
\hline & 50 & $1.78 \pm 0.14$ & 42.2 & $4.49 \pm 0.52$ & $6.09 \pm 1.00$ & $2.42 \pm 0.09$ & $1.42 \pm 0.88$ \\
\hline & 75 & $1.75 \pm 0.43^{*}$ & 44.4 & $6.46 \pm 0.48^{*}$ & $7.08 \pm 1.34 *$ & $2.99 \pm 0.90$ & $1.40 \pm 0.36$ \\
\hline & 100 & $1.51 \pm 0.54^{*}$ & 62.2 & $8.98 \pm 1.23^{*}$ & $10.08 \pm 2.10 *$ & $2.32 \pm 0.93$ & $1.76 \pm 0.78$ \\
\hline & 150 & $1.20 \pm 0.13^{*}$ & 85.2 & n. e. & n. e. & n. e. & n. e. \\
\hline Pos. Cont. & $1 \mu \mathrm{g} / \mathrm{mL}$ & $1.68 \pm 0.09$ & & $45.21 \pm 5.20 *$ & $53.21 \pm 7.60^{*}$ & $10.34 \pm 3.20^{*}$ & $2.05 \pm 1.06$ \\
\hline
\end{tabular}

Human mitogen-stimulated lymphocytes from three individuals were treated with different concentrations of the test compounds for $3 \mathrm{~h}$. TR-146 cells were exposed to different concentrations of the drugs for $24 \mathrm{~h}$. Numbers represent results (means \pm SDs) obtained with duplicate cultures from four donors. Per experimental point, two slides were prepared and 1000 cells were evaluated from each slide

n.e. not evaluated due to inhibition of cell division

Please exchange $\mathrm{C}^{+}$to Pos. Cont. mitomycin C $(1.0 \mu \mathrm{g} / \mathrm{ml})$

$C B P I$ cytokinesis-block proliferation indices, $C T$ cytostasis (\%); BN-MNi binucleated cells with micronuclei, $M N i$ total number of micronuclei, Nbuds nuclear buds, $N P B s$ nucleoplasmic bridges, $O$ solvent control (DMSO), $C^{+}$mitomycin C $(1.0 \mu \mathrm{g} / \mathrm{mL})$

* Significant differences from negative control (Kruskal-Wallis test followed by Dunns's test, $p \leq 0.05$ )

a Number of binucleated cell with micronuclei

b Total number of MN

alkylindazoles (AM-2201-IC and 5F-AKB-48), positive findings were obtained in human blood cells (Koller et al. 2015) and representatives of naphthoylindoles (JWH-122 and JWH-073) induced DNA migration in buccal-derived cells (Koller et al. 2013). The concentrations of the drugs which were required to cause significant effects were in most cases in the range between 50 and $100 \mu \mathrm{M}$; only with one compound (CP-47,497-C8), significant induction of DNA migration was seen at a substantially lower dose $(10 \mu \mathrm{M})$. Also with $\Delta^{9}$-THC, induction of comets has been reported, for example, in the human-derived buccal cell line which was also used in the present experiments (Koller et al. 2013) and also in an environmental study with mussels (Parolini and Binelli 2014).

It is not known in general whether positive results in SCGE experiments lead to persisting alterations of the genetic material. In order to find out whether the two drugs cause damage at the chromosomal level which is associated with adverse health effects, we conducted cytome assays in which we studied the formation of $\mathrm{MNi}$ which are a consequence 
of structural and numerical aberrations (Norppa and Falck 2003) as well as other nuclear anomalies. As described in the results sections (Table 2), positive results were obtained with both drugs in the buccal cell line (TR-146) and also in the lymphocytes. Also the rates of other nuclear anomalies namely Nbuds and NPBs lower elevated after treatment of the lymphocytes with XLR-11. It is known that these anomalies reflect genetic instability; i.e., NPBs are formed as a consequence of dicentric chromosomes while Nbuds reflect gene amplification events (Fenech et al. 2011). The biological consequences of the formation of these anomalies are not known at present; in the case of $\mathrm{MNi}$, it is notable and it was shown by Bonassi and co-workers that increased rates of $\mathrm{MN}$ in peripheral lymphocytes of humans are associated with elevated cancer risks (Bonassi et al. 2007, 2011).

The results of the present experiments allow to draw some conclusions in regard to the molecular mechanisms which lead to damage of the genetic material. The negative results in the bacterial assays indicate that the drugs do not form bulky DNA adducts as other groups of genotoxic carcinogens (e.g., aflatoxins, polycyclic aromatic hydrocarbons or heterocyclic amines) which cause gene mutations and lead to formation of his ${ }^{+}$revertants. Furthermore, it can be also excluded that the induction of the comets which was observed in the SCGE experiments is causally related to formation of oxidatively damaged purines and pyrimidines. As shown in Fig. 3a-d, negative results were consistently obtained in experiments with lesion-specific enzymes (FPG, Endo III) which enable the detection of oxidized DNA bases (Collins 2014). In this context, it is notable that it was found in earlier investigations that the natural cannabinoid $\Delta^{9}$-THC induces oxidative damage in eukaryotic cells (Juknat et al. 2013; Parolini and Binelli 2014; Sarafian et al. 1999); furthermore, SCs were reported to cause induction of pro-inflammatory cytokines which may lead to release of reactive oxygen species (Bileck et al. 2015; Jean-Gilles et al. 2015).

Many genotoxic carcinogens require metabolic activation via phase I enzymes. To mimic these metabolic processes which lead to formation of DNA-reactive metabolites in vivo, liver enzyme homogenate ( $\mathrm{S} 9 \mathrm{mix}$ ) is added in routine mutagenicity assays (OECD 1997, 2010). As shown in Fig. 4a, b, we found that addition of the enzyme homogenate leads to a moderate (not significant) decrease in the genotoxic properties of both drugs. A similar effect was seen when BSA was added to the incubation mixtures. These findings show that enzymes which are contained in liver homogenates do not convert these drugs to DNAreactive intermediates. The observation of a reduction in their genotoxic activity which was seen with the enzyme mix and with pure proteins may be indicative of detoxification via (non-enzymatic) protein binding. Similar, but more pronounced effects were seen in previous experiments with the SC, CP-47,497-C8 (Koller et al. 2014) and also with representatives of other groups of directly acting mutagens for example with isothiocyanates and alkylating agents (Kassie and Knasmuller 2000). It is possible that these detoxification reactions play also a role in the human body in addition to metabolic processes which are catalyzed by enzymes (e.g., hydroxylation, carboxylation and glucuronidation) which were observed recently in in vitro experiments with XLR-11 (Wohlfarth et al. 2013).

The last part of this study concerned the question whether the drugs cause DNA damage under realistic exposure conditions. Only for few SCs (including RCS-4), data on their concentrations in body fluids of humans after consumption of the drugs are available (Kneisel et al. 2013; Teske et al. 2010). The concentrations which were detected are $2-3$ orders of magnitude lower than those which caused positive results in the present experiments. In order to assess whether induction of genetic damage occurs in users as a consequence of inhalation of the drugs, we conducted with both SCs experiments with an air-liquid interface system. As described above, the cells were grown on membranes and exposed to drugs under conditions which mimic the exposure of tissues in the respiratory tract. The amounts which were vaporized (5 and $20 \mathrm{mg}$ ) are contained in 1-2 typical SC containing cigarettes (Adamowicz et al. 2013). As described in the results section, we found with both SCs clear evidence for induction of DNA migration in both types of indicator cells.

Taken together, the results of the present study show that both drugs cause DNA instability in human-derived cells at the chromosomal level. It is known that instability of the genetic material plays a key role in the etiology of human cancer (Ferguson et al. 2015). Furthermore, it is also involved in neurodegenerative disorders (Madabhushi et al. 2014), infertility (Evgeni et al. 2015) and accelerated aging (Ermolaeva and Schumacher 2014). Therefore, the findings of our investigation indicate that adverse health effects may be caused in drug users as a consequence of the DNA-damaging properties of the drugs, and further investigations are warranted to clarify this important issue.

Acknowledgments Open access funding was provided by Medical University of Vienna. This study was supported by the Austrian Federal Ministry of Health and by the EU in the frame of the projects BMG-237609/0001-I/3/13 and "SPICE II Plus" (JUST/2011/DPIP/ AG/3597).

\section{Compliance with ethical standards}

Conflict of interest The authors state that they have no conflict of interest.

Open Access This article is distributed under the terms of the Creative Commons Attribution 4.0 International License (http://creativecommons.org/licenses/by/4.0/), which permits unrestricted use, distribution, and reproduction in any medium, provided you give appropriate credit to the original author(s) and the source, provide a link to the Creative Commons license, and indicate if changes were made. 


\section{References}

Adamowicz P, Zuba D, Sekula K (2013) Analysis of UR-144 and its pyrolysis product in blood and their metabolites in urine. Forensic Sci Int 233(1-3):320-327

Ames BN, Gold LS (1997) The causes and prevention of cancer: gaining perspective. Environ Health Perspect 105(Suppl 4):865-873

Ames BN, Shigenaga MK, Hagen TM (1993) Oxidants, antioxidants, and the degenerative diseases of aging. Proc Natl Acad Sci USA 90(17):7915-7922

Bileck A, Koller V, Ferk F et al (2015) Impact of a synthetic cannabinoid (CP-47,497-C8) on protein expression in human cells: evidence for induction of inflammations and DNA-damage. Arch Toxicol (Published online 21 July 2015)

Bonassi S, Znaor A, Ceppi M et al (2007) An increased micronucleus frequency in peripheral blood lymphocytes predicts the risk of cancer in humans. Carcinogenesis 28(3):625-631

Bonassi S, El-Zein R, Bolognesi C, Fenech M (2011) Micronuclei frequency in peripheral blood lymphocytes and cancer risk: evidence from human studies. Mutagenesis 26(1):93-100

Collins AR (2014) Measuring oxidative damage to DNA and its repair with the comet assay. Biochim Biophys Acta 1840(2):794-800

Collins A, Dušinská M (2002) Oxidation of cellular DNA measured with the comet assay. In: Armstrong D (ed) Oxidative stress biomarkers and antioxidant protocols. Methods in molecular biology. Humana Press Inc., Totowa, pp 147-160

Collins AR, Dobson VL, Dusinska M, Kennedy G, Stetina R (1997) The comet assay: what can it really tell us? Mutat Res 375(2):183-193

Ermolaeva MA, Schumacher B (2014) Systemic DNA damage responses: organismal adaptations to genome instability. Trends Genet 30(3):95-102

Evgeni E, Lymberopoulos G, Gazouli M, Asimakopoulos B (2015) Conventional semen parameters and DNA fragmentation in relation to fertility status in a Greek population. Eur J Obstet Gynecol Reprod Biol 188:17-23

Fenech M (2007) Cytokinesis-block micronucleus cytome assay. Nat Protoc 2(5):1084-1104

Fenech M, Kirsch-Volders M, Natarajan AT et al (2011) Molecular mechanisms of micronucleus, nucleoplasmic bridge and nuclear bud formation in mammalian and human cells. Mutagenesis 26(1):125-132

Ferguson LR, Chen H, Collins AR, Connell M, Damia G, Dasgupta S, Malhotra M et al (2015) Genomic instability in human cancer: molecular insights and opportunities for therapeutic attack and prevention through diet and nutrition. Semin Cancer Biol. doi:10.1016/j.semcancer.2015.03.005

Fluckiger-Isler S, Kamber M (2012) Direct comparison of the Ames microplate format (MPF) test in liquid medium with the standard Ames pre-incubation assay on agar plates by use of equivocal to weakly positive test compounds. Mutat Res 747(1):36-45

Henderson L, Wolfreys A, Fedyk J, Bourner C, Windebank S (1998) The ability of the Comet assay to discriminate between genotoxins and cytotoxins. Mutagenesis 13(1):89-94

Huppertz LM, Kneisel S, Auwarter V, Kempf J (2014) A comprehensive library-based, automated screening procedure for 46 synthetic cannabinoids in serum employing liquid chromatographyquadrupole ion trap mass spectrometry with high-temperature electrospray ionization. J Mass Spectrom 49(2):117-127

Jean-Gilles L, Braitch M, Latif ML et al (2015) Effects of pro-inflammatory cytokines on cannabinoid $\mathrm{CB} 1$ and $\mathrm{CB} 2$ receptors in immune cells. Acta Physiol (Oxf) 214(1):63-74

Juknat A, Pietr M, Kozela E et al (2013) Microarray and pathway analysis reveal distinct mechanisms underlying cannabinoidmediated modulation of LPS-induced activation of BV-2 microglial cells. PLoS ONE 8(4):e61462
Kassie F, Knasmuller S (2000) Genotoxic effects of allyl isothiocyanate (AITC) and phenethyl isothiocyanate (PEITC). Chem Biol Interact 127(2): 163-180

Kneisel S, Auwarter V, Kempf J (2013) Analysis of 30 synthetic cannabinoids in oral fluid using liquid chromatography-electrospray ionization tandem mass spectrometry. Drug Test Anal 5(8):657-669

Koller VJ, Zlabinger GJ, Auwarter V, Fuchs S, Knasmueller S (2013) Toxicological profiles of selected synthetic cannabinoids showing high binding affinities to the cannabinoid receptor subtype CB(1). Arch Toxicol 87(7):1287-1297

Koller VJ, Auwarter V, Grummt T, Moosmann B, Misik M, Knasmuller $S$ (2014) Investigation of the in vitro toxicological properties of the synthetic cannabimimetic drug CP-47,497-C8. Toxicol Appl Pharmacol 277(2):164-171

Koller VJ, Ferk F, Al-Serori H et al (2015) Genotoxic properties of representatives of alkylindazoles and aminoalkyl-indoles which are consumed as synthetic cannabinoids. Food Chem Toxicol 80:130-136

Lieber M, Smith B, Szakal A, Nelson-Rees W, Todaro G (1976) A continuous tumor-cell line from a human lung carcinoma with properties of type II alveolar epithelial cells. Int J Cancer 17(1):62-70

Lindl T, Bauer J (1994) Zell- und Gewebekultur, 3rd edn. Gustave Fischer, Stuttgart

Logan BK, Reinhold LE, Xu A, Diamond FX (2012) Identification of synthetic cannabinoids in herbal incense blends in the United States. J Forensic Sci 57(5):1168-1180

Madabhushi R, Pan L, Tsai LH (2014) DNA damage and its links to neurodegeneration. Neuron 83(2):266-282

Majeed S, Frentzel S, Wagner S et al (2014) Characterization of the Vitrocell(R) 24/48 in vitro aerosol exposure system using mainstream cigarette smoke. Chem Cent J 8(1):62

Maron DM, Ames BN (1983) Revised methods for the Salmonella mutagenicity test. Mutat Res 113(3-4):173-215

Mohr AL, Ofsa B, Keil AM, Simon JR, McMullin M, Logan BK (2014) Enzyme-linked immunosorbent assay (ELISA) for the detection of use of the synthetic cannabinoid agonists UR-144 and XLR-11 in human urine. J Anal Toxicol 38(7):427-431

Norppa H, Falck GC (2003) What do human micronuclei contain? Mutagenesis 18(3):221-233

NTP (1996) National Toxicology Program-toxicology and carcinogenesis studies of 1-trans-delta(9)-tetrahydrocannabinol (CAS No. 1972-08-3) in F344 Rats and B6C3F1 Mice (Gavage Studies). Natl Toxicol Program Tech Rep Ser 446:1-317

OECD (1997) Test no. 471: bacterial reverse mutation test. OECD (Organisation for Economic Co-operation and Development) guidelines for the testing of chemicals, section 4. OECD Publishing, Paris. doi:10.1787/9789264071247-en

OECD (2010) Test no. 487: in vitro mammalian cell micronucleus test. OECD (Organisation for Economic Co-operation and Development) guidelines for the testing of chemicals, section 4 . OECD Publishing, Paris. doi:10.1787/9789264091016-en

Parolini M, Binelli A (2014) Oxidative and genetic responses induced by Delta-9-tetrahydrocannabinol (Delta-9-THC) to Dreissena polymorpha. Sci Total Environ 468-469:68-76

Rupniak HT, Rowlatt C, Lane EB et al (1985) Characteristics of four new human cell lines derived from squamous cell carcinomas of the head and neck. J Natl Cancer Inst 75(4):621-635

Sarafian TA, Magallanes JA, Shau H, Tashkin D, Roth MD (1999) Oxidative stress produced by marijuana smoke. An adverse effect enhanced by cannabinoids. Am J Respir Cell Mol Biol 20(6):1286-1293

Seely KA, Patton AL, Moran CL et al (2013) Forensic investigation of K2, Spice, and "bath salt" commercial preparations: a threeyear study of new designer drug products containing synthetic cannabinoid, stimulant, and hallucinogenic compounds. Forensic Sci Int 233(1-3):416-422 
Spaderna M, Addy PH, D’Souza DC (2013) Spicing things up: synthetic cannabinoids. Psychopharmacology 228(4):525-540

Tang T, Gminski R, Könczöl M, Modest C, Armbruster B, MerschSundermann V (2012) Investigations on cytotoxic and genotoxic effects of laser printer emissions in human epithelial A549 lung cells using an air/liquid exposure system. Environ Mol Mutagen 53(2): $125-135$

Teske J, Weller JP, Fieguth A, Rothamel T, Schulz Y, Troger HD (2010) Sensitive and rapid quantification of the cannabinoid receptor agonist naphthalen-1-yl-(1-pentylindol-3-yl)methanone (JWH-018) in human serum by liquid chromatography-tandem mass spectrometry. J Chromatogr, B: Anal Technol Biomed Life Sci 878(27):2659-2663

Thorne D, Adamson J (2013) A review of in vitro cigarette smoke exposure systems. Exp Toxicol Pathol 65(7-8):1183-1193

Tice RR, Agurell E, Anderson D et al (2000) Single cell gel/comet assay: guidelines for in vitro and in vivo genetic toxicology testing. Environ Mol Mutagen 35(3):206-221
Uchiyama N, Kawamura M, Kikura-Hanajiri R, Goda Y (2013) URB754: a new class of designer drug and 12 synthetic cannabinoids detected in illegal products. Forensic Sci Int 227(1-3):21-32

Weber S, Hebestreit M, Wilms T, Conroy LL, Rodrigo G (2013) Comet assay and air-liquid interface exposure system: a new combination to evaluate genotoxic effects of cigarette whole smoke in human lung cell lines. Toxicol In Vitro 27(6):1987-1991

Wiley JL, Marusich JA, Lefever TW, Grabenauer M, Moore KN, Thomas BF (2013) Cannabinoids in disguise: Delta9-tetrahydrocannabinol-like effects of tetramethyl-cyclopropyl ketone indoles. Neuropharmacology 75:145-154

Wohlfarth A, Pang S, Zhu M et al (2013) First metabolic profile of XLR-11, a novel synthetic cannabinoid, obtained by using human hepatocytes and high-resolution mass spectrometry. Clin Chem 59(11):1638-1648 